\title{
Mushroom as a product and their role in mycoremediation
}

\author{
Shweta Kulshreshtha ${ }^{{ }^{*}}$, Nupur Mathur ${ }^{2}$ and Pradeep Bhatnagar ${ }^{3}$
}

\begin{abstract}
Mushroom has been used for consumption as product for a long time due to their flavor and richness in protein. Mushrooms are also known as mycoremediation tool because of their use in remediation of different types of pollutants. Mycoremediation relies on the efficient enzymes, produced by mushroom, for the degradation of various types of substrate and pollutants. Besides waste degradation, mushroom produced a vendible product for consumption. However, sometimes they absorb the pollutant in their mycelium (biosorption process) and cannot be consumed due to absorbed toxicants. This article reviews the achievement and current status of mycoremediation technology based on mushroom cultivation for the remediation of waste and also emphasizes on the importance of mushroom as product. This critical review is also focused on the safety aspects of mushroom cultivation on waste.
\end{abstract}

Keywords: Biodegradation; Bioremediation; Genotoxicity; Biosorption; Mushroom; Ames test; Product; Industrial waste; Agroindustrial waste; Bioconversion

\section{Introduction}

Biological approaches based on industrial and environmental biotechnology is focusing on the development of "clean technologies" which emphasizes on the maximum production, reduced waste generation, treatment and conversion of waste in some useful form. Further, these clean technologies focus on the use of biological methods for the remediation of waste. One such biological method is mycoremediation which is based on the use of fungi and mushroom for the removal of waste from the environment. The mushrooms and other fungi possess enzymatic machinery for the degradation of waste/pollutants and therefore, can be applied for a wide variety of pollutants (Purnomo et al. 2013; Kulshreshtha et al. 2013). However, mushrooms, a basidiomycetous fungus, are becoming more popular nowadays for remediation purposes because it is not only a bioremediation tool but also provide mycelium or fruiting bodies as a source of protein. The efficiency of mushroom species in producing food protein in the form of biomass or fruiting bodies from different wastes lies in their ability to degrade waste via secretion of a variety of

\footnotetext{
* Correspondence: shweta_kulshreshtha@rediffmail.com

${ }^{1}$ Amity Institute of Biotechnology, Amity University Rajasthan, 14- Gopal Bari, Ajmer Road, A-200, Vaishali Nagar, Jaipur 302021, Rajasthan, India Full list of author information is available at the end of the article
}

hydrolyzing and oxidizing enzymes (Kuforiji and Fasidi 2008; Zhu et al. 2013). This has attracted research attention in the field of mushroom cultivation and waste remediation.

Many reports have published to emphasize the role of mushroom in bioremediation of wastes by the process of biodegradation, biosorption and bioconversion (Akinyele et al. 2012, Kulshreshtha et al. 2013a; Kumhomkul and Panich-pat 2013; Lamrood and Ralegankar 2013). Many scientists have studied the role of different enzymes in the degradation process; degradation products formed by it and conditions affecting the degradation process (Novotný et al. 2004; Akinyele et al. 2011; Zhu et al. 2013). However, safety aspects of the process and products have not been reported so far. There is scarcity of reports indicating the pros and cons of mushroom cultivation on wastes and their further utilization as food. Moreover, mushroom as a product is meagerly reported.

Keeping this in mind, in this review we are discussing the use of mushroom as a biological tool for cleanup the environment. Mushroom is not only a mycoremediation tool but also a product. Mushroom fruiting bodies generated on industrial and agro-industrial wastes are considered as a product. We have also focused on the safety aspects of mushroom cultivation on waste. 


\section{Mushroom as a product}

Mushrooms are the product of biological origin and can be developed from biological wastes, agricultural wastes, agro-industrial wastes and industrial wastes. Besides this, these mushrooms can be used as a source of proteins, amino acids and several biological active molecules which not only provide nutrition but also use for therapeutic purposes (Table 1). Therefore, these can be considered as an important product.

Edible mushrooms are highly nutritious and can be compared with eggs, milk and meat (Oei 2003). Mushroom is a protein rich food and has been considered as the source of single cell protein. These are easily digestible and possess a high amount of amino acids but lacks cholesterol. These possess high quantities of fibers, few sugars and low calories and a high quantity of the amino acids phenylalanine, threonine and tyrosine.

As far as the nutrient profile of mushroom are concerned, these are influenced by many factors including the type of substrate on which these are cultivated. There are some differences in the nutrient content of the mushroom cultivated on different substrates (Mabrouk and Ahwanyi 2008; Akinyele et al. 2011; Kulshreshtha et al. 2013b). However, this change in nutritional content never found to affect their edibility. Therefore, it is still a beneficial technology because it solves two major problems simultaneously i.e. waste accumulation and shortage of proteinaceous food.

Besides, use for edible purpose, mushroom is used for other industrial processes like biopulping and biobleaching. Hence, the importance of this as product cannot be ignored.

\section{Mushroom as mycoremediation tool}

Remediation through fungi is also called as mycoremediation. Mycoremediation tool refers to mushrooms and their enzymes due to having ability to degrade a wide variety of environmentally persistent pollutants, transform industrial and agro-industrial wastes into products.

\section{Mycoremediation potential of mushroom}

Mushroom uses different methods to decontaminate polluted spots and stimulate the environment. These methods include - (i) Biodegradation (ii) Biosorption (iii) Bioconversion.

\section{Biodegradation}

The term 'Biodegradation' is used to describe the ultimate degradation and recycling of complex molecule to its mineral constituents. It is the process which leads to complete mineralization of the starting compound to simpler ones like $\mathrm{CO}_{2}, \mathrm{H}_{2} \mathrm{O}, \mathrm{NO}_{3}$ and other inorganic compounds by living organisms. A lot of research has been done on the degradation abilities of mushroom and their enzymes and is depicted in Table 2. Many reports have been published on the compounds produced by degradation of various wastes and factor affecting the processes.

Mushroom can produce extracellular peroxidases, ligninase (lignin peroxidase, manganese dependent peroxidase and laccase), cellulases, pectinases, xylanases and oxidases (Nyanhongo et al. 2007). These are able to oxidize recalcitrant pollutants in vitro. These enzymes are typically induced by their substrates.

These enzymes have also been found to degrade nonpolymeric, recalcitrant pollutants such as nitrotoluenes (VanAcken et al. 1999), PAHs (Hammel et al. 1991; Johannes et al. 1996), organic and synthetic dyes (Ollikka et al. 1993; Heinfling et al. 1998), and pentachlorophenol (Lin et al. 1990) under in vitro conditions. Recently, it is reported that mushroom species are able to degrade polymers such as plastics (da Luz et al. 2013).

The biodegradation mechanism is very complex. The reason is the influence of other biochemical systems and interactions of ligninolytic enzymes with cytochrome $\mathrm{P}_{450}$ monooxygenase system, hydroxyl radicals and the level of $\mathrm{H}_{2} \mathrm{O}_{2}$ which are produced by the mushroom.

\section{Biosorption}

The second important process of removal of metals/pollutants from the environment by mushroom is - biosorption. Biosorption is considered as an alternative to the remediation of industrial effluents as well as the recovery of metals present in effluent. Biosorption is a process based on the sorption of metallic ions/pollutants/xenobiotics from effluent by live or dried biomass which often exhibits a marked tolerance towards metals and other adverse

\section{Table 1 Role of mushroom as an important product}

\begin{tabular}{|c|c|c|c|}
\hline S. no. & Mushroom & As a product & References \\
\hline 1 & $\begin{array}{l}\text { Pleurotus, Agaricus, Ganoderma Schizophyllan commune, } \\
\text { Grifola frondosa Coriolus versicolor, Ganoderma lucidum, }\end{array}$ & $\begin{array}{l}\text { Used as medicine to boost immune } \\
\text { responses against cancer }\end{array}$ & $\begin{array}{l}\text { Kodama et al. (2002); Gao et al. (2003); } \\
\text { Maehara et al. (2012) }\end{array}$ \\
\hline 2 & Pleurotus, Agaricus, & $\begin{array}{l}\text { Possess antimutagenic or antigenotoxic } \\
\text { power to fight against cancer }\end{array}$ & Gameiro et al. (2013); Kang et al. (2012) \\
\hline 3 & $\begin{array}{l}\text { Ganoderma lucidum, Phellinus rimosus, Pleurotus florida } \\
\text { and Pleurotus pulmonaris }\end{array}$ & Used as antioxidant and antitumor agent & Ajith and Janardhanan (2007) \\
\hline 4 & Pleurotus, Agaricus & Used as food & \\
\hline
\end{tabular}


Table 2 Role of mushroom in degradation of pollutants

\begin{tabular}{|c|c|c|c|c|}
\hline S. no. & Mushroom spp. & Waste/Pollutants & Remarks & References \\
\hline 1 & Pleurotus ostreatus & $\begin{array}{l}\text { Oxo-Biodegradable } \\
\text { plastic }\end{array}$ & Mushrooms degraded the plastic and grew on it. & da Luz et al. (2013) \\
\hline 2 & Lentinula edodes & 2,4-dichlorophenol & $\begin{array}{l}\text { Mushrooms degraded 2,4-dichlorophenol (DCP) } \\
\text { by using vanillin as an activator }\end{array}$ & Tsujiyama et al. (2013) \\
\hline 3 & Pleurotus pulmonarius & $\begin{array}{l}\text { Radioactive cellulosic- } \\
\text { based waste }\end{array}$ & $\begin{array}{l}\text { Waste containing mushroom mycellium was solidified } \\
\text { with portland cement and then this solidified waste } \\
\text { act as first barrier against the release of radiocontaminants }\end{array}$ & Eskander et al. (2012) \\
\hline 4 & $\begin{array}{l}\text { Jelly sp., Schizophyllum } \\
\text { commune and Polyporous sp. }\end{array}$ & malachite green & $\begin{array}{l}99.75 \% \text { (Jelly sp.), } 97.5 \% \text { (Schizophyllum commune), } 68.5 \% \\
\text { (Polyporous sp.2) dye was degraded in } 10 \text { days }\end{array}$ & Rajput et al. (2011) \\
\hline 5 & Pleurotus pulmonarius & crude oil & crude oil was degraded & $\begin{array}{l}\text { Olusola and Anslem } \\
\text { (2010) }\end{array}$ \\
\hline 6 & $\begin{array}{l}\text { Coriolus versicolor } \\
\text { MKACC } 52492\end{array}$ & $\mathrm{PAH}$ & $\begin{array}{l}\text { Mushroom possesses ability to degrade Poly-R } 478 \text { which } \\
\text { decides its suitability to degrade PAH. Lignin-modifying } \\
\text { enzymes laccase, manganese-dependent peroxidase } \\
\text { (MnP), and lignin peroxidase (LiP)was found to produce } \\
\text { for degradation }\end{array}$ & Jang et al. (2009) \\
\hline
\end{tabular}

conditions (Gavrilescu 2004). Biosorbents can be prepared from mushroom mycelium and spent mushroom compost.

The uptake of pollutants/xenobiotics by mushrooms involves a combination of two processes: (i) bioaccumulation i.e. active metabolism-dependent processes, which includes both transport into the cell and partitioning into intracellular components; and (ii) biosorption i.e. the binding of pollutants to the biomass without requiring metabolic energy. Several chemical processes may be involved in biosorption, including adsorption, ion exchange processes and covalent binding. According to Mar'in et al. (1997), the polar groups of proteins, amino acids, lipids and structural polysaccharides (chitin, chitosan, glucans) may be involved in the process of biosorption.

A lot of study has been done on the biosorptive capacity of biomass of mushroom and are shown in Table 3. It is reported that the biosorption capacity of dead biomass may be greater, similar to or less than that of living cells (Mar'in et al. 1997). In the case of biosorption, dead biomass of mushroom offers certain advantages over living cells. Dead mushroom biomass can be obtained from industries as a waste of fermentation processes. Further, this is not sensitive to concentrations of toxicants and their toxicity effects and adverse operating conditions $(\mathrm{pH}$, temperature, nutrient supply, initial metal ion concentration, and the concentration of cells etc.) unlike living mushroom biomass. The uptake of xenobiotic by living cells depends on fungal species and contact time. Biosorption techniques are now becoming very popular for the removal of pollutants. Biosorption is an effective method due to the high uptake capacity and very costeffective source of the raw material.

\section{Bioconversion}

Nowadays, the research on conversion of industrial or agro-industrial sludges into some other useful forms is going on. The most important bioconversion product is - mushroom. Any lignocellulosic waste, generated by

Table 3 Removal of pollutants by biomass of mushroom using biosorption process

\begin{tabular}{|c|c|c|c|c|}
\hline S. no & Mushroom spp. & Pollutants & Remarks & References \\
\hline 1 & $\begin{array}{l}\text { Agaricus bisporus, } \\
\text { Lactarius piperatus }\end{array}$ & Cadmium (II) ions & $\begin{array}{l}\text { Wild L. piperatus showed higher removal efficiency } \\
\text { on } \mathrm{Cd}(\mathrm{II}) \text { ions compared to the cultivated A. bisporus }\end{array}$ & Nagy et al. (2013) \\
\hline 2 & Fomes fasciatus & Copper (II) & $\begin{array}{l}\text { Mushroom is efficient in biosorption of } \mathrm{Cu}(\mathrm{II}) \text { ions and } \\
\text { hot-alkali treatment increased their affinity for } \mathrm{Cu}(\mathrm{II}) \text { ions }\end{array}$ & $\begin{array}{l}\text { Sutherland and Venkobachar } \\
\text { (2013) }\end{array}$ \\
\hline 3 & $\begin{array}{l}\text { Pleurotus platypus, Agaricus } \\
\text { bisporus, Calocybe indica }\end{array}$ & $\begin{array}{l}\text { Copper, Zinc, Iron, } \\
\text { Cadmium, Lead, Nickle }\end{array}$ & $\begin{array}{l}\text { Mushrooms are efficient biosorbent for the } \\
\text { removal these ions from aqueous solution }\end{array}$ & $\begin{array}{l}\text { Lamrood and Ralegankar } \\
\text { (2013) }\end{array}$ \\
\hline 4 & Flammulina velutipes & Copper & $\begin{array}{l}\text { Mushroom compost used as biosorbent for } \\
\text { removing copper ions from aqueous solution }\end{array}$ & Luo et al. (2013) \\
\hline 5 & Pleurotus tuber- regium & Heavy metals & $\begin{array}{l}\text { Pleurotus tuber-regium biosorb the pollutant heavy } \\
\text { metals from the soil artificially contaminated } \\
\text { with some heavy metals }\end{array}$ & Oyetayo et al. (2012) \\
\hline 6 & Pleurotus ostreatus & Cadmium & $\begin{array}{l}\text { Mushroom possess biosorption capacity and } \\
\text { mechanism of biosorption was observed }\end{array}$ & Tay et al. (2011) \\
\hline 7 & Pleurotus sajor-caju & heavy metal Zn & Mushrooms biosorb the heavy metals & Jibran and Milsee Mol (2011) \\
\hline
\end{tabular}


industries, can be used for cultivation of mushroom which can be further use as a product. Mushroom species cultivated on industrial and agro-industrial wastes are given in Table 4. The choice of the substrate for the cultivation of mushroom is generally determined by the regional availability of the material.

Mushroom cultivation has also been successfully done on various industrial wastes (Singhal et al. 2005; Kulshreshtha et al. 2010; Dulay et al. 2012 and Kulshreshtha et al. 2013b). Applications of mushroom as mycoremediation tool in the bioconversion of these industrial wastes into protein rich mushroom carpophores (fruiting bodies of mushroom), on one hand provides mushroom and on the other hand helps in solving pollution problems, which their disposal may otherwise cause.

Feasibility of the mycoremediation tool and processes It is extremely important to carry out feasibility study before starting a remediation project in order to determine the best conditions for the process and toxicity in the fruiting bodies. The most important parameters to define a contaminated site are: biodegradability, contaminant distribution, chemical reactivity of the contaminants, soil type and properties, oxygen availability and occurrence of inhibitory substances (Martín et al. 2004). The success of mycoremediation is governed by three important factorsavailability of mushroom, accessibility of contaminants and a conductive environment. Therefore, the knowledge on the physiology and ecology of the biological species or consortia involved and the characteristics of the polluted sites are decisive factors to select an adequate mycoremediation protocol (Martín et al. 2004).

Mycoremediation of waste from the environment by mushroom has many advantages but at the same time it is a challenge for the researchers and engineers. Mycoremediation of wastes can be done in in situ and ex situ conditions. When it is carried out on site, it eliminates the need to transport the toxic materials to treatment

Table 4 Bioconversion of waste by mushroom species

\begin{tabular}{|c|c|c|c|c|}
\hline S. no. & Mushroom spp. & Bioconversion of waste & Remarks & References \\
\hline 1 & Pleurotus citrinopileatus & $\begin{array}{l}\text { Handmade paper and cardboard } \\
\text { industrial waste }\end{array}$ & $\begin{array}{l}\text { Successfully cultivated. Basidiocarps } \\
\text { possessed good nutrient content and } \\
\text { no genotoxicity }\end{array}$ & Kulshreshtha et al. (2013) \\
\hline 2 & Pleurotus ostreatus & Extract from the sawdust & $\begin{array}{l}\text { Biomass of mushroom was produced in } \\
\text { submerged liquid culture were analyzed }\end{array}$ & Akinyele et al. (2012) \\
\hline 3 & Volvariella volvacea & $\begin{array}{l}\text { Agro-industrial residues such as cassava, } \\
\text { sugar beet pulp, wheat bran and } \\
\text { apple pomase }\end{array}$ & $\begin{array}{l}\text { Enzyme activities were measured during } \\
\text { the fermentation of substrates }\end{array}$ & Akinyele et al. (2011) \\
\hline 4 & Pleurotus florida & $\begin{array}{l}\text { Handmade paper and cardboard } \\
\text { industrial waste }\end{array}$ & $\begin{array}{l}\text { Successfully cultivated. Basidiocarps } \\
\text { possessed normal morphology and } \\
\text { no genotoxicity }\end{array}$ & Kulshreshtha et al. (2010) \\
\hline 5 & Pleurotus & $\begin{array}{l}\text { Cotton waste, rice straw, cocoyam peels } \\
\text { and sawdusts of Mansonia altissima, } \\
\text { Boscia angustifolia and Khaya ivorensis }\end{array}$ & $\begin{array}{l}\text { Successfully cultivated with good crude } \\
\text { protein, crude fat and carbohydrate } \\
\text { contents in sporophores. }\end{array}$ & Kuforiji and Fasidi (2009) \\
\hline 6 & $\begin{array}{l}\text { Pleurotus eous and } \\
\text { Lentinus connotus }\end{array}$ & $\begin{array}{l}\text { Paddy straw, sorghum stalk, and banana } \\
\text { pseudostem }\end{array}$ & $\begin{array}{l}\text { Waste successfully bioconverted by } \\
\text { mushroom with good biological efficiency }\end{array}$ & Rani et al. (2008) \\
\hline 7 & Pleurotus tuber-regium & $\begin{array}{l}\text { Nigerian trees; Terminalia superba, } \\
\text { Mansonia altissima, Holoptelia grandis } \\
\text { and Miliciaexcelsa }\end{array}$ & Grow on trees & Jonathan et al. (2008) \\
\hline 8 & Pleurotus tuber-regium & $\begin{array}{l}\text { Cotton waste, sawdust of Khaya ivorensis } \\
\text { and rice straw }\end{array}$ & $\begin{array}{l}\text { Sclerotia propagated on groundnut shells } \\
\text { and cocoyam peels with lipase and } \\
\text { phenoloxidase; cellulase, carboxymethyl } \\
\text { cellulase enzymatic activities }\end{array}$ & Kuforiji and Fasidi (2008) \\
\hline 9 & Lentinula edodes & Eucalyptus waste & $\begin{array}{l}\text { Successfully convert this waste and } \\
\text { qualitative and quantitative changes } \\
\text { were also measured }\end{array}$ & Brienzo et al. (2007) \\
\hline 10 & Lentinula edodes & $\begin{array}{l}\text { Vineyard pruning (VP), barley straw (BS), } \\
\text { and wheat straw }\end{array}$ & $\begin{array}{l}\text { Bioconversion of VP waste with shortest } \\
\text { primordium formation, highest biological } \\
\text { efficiency, highest yield and shortest } \\
\text { production cycle ( } 6 \text { days) }\end{array}$ & Gaitán- Hernández et al. (2006) \\
\hline 11 & Lentinula tigrinus & Wheat straw & $\begin{array}{l}\text { Characterize the production of } \\
\text { lignocellulosic enzymes and bioconvert } \\
\text { the wheat straw }\end{array}$ & Lechner and Papinutti (2006) \\
\hline 12 & V. volvacea & Banana leaves (Musa sapientum lina) & Efficient bioconversion with good yield & Belewu and Belewu (2005) \\
\hline
\end{tabular}


sites. It is an environmentally friendly approach and needs only a small space, low cost, less skilled persons and can be applied easily in the field. In contrast to above, there are some disadvantages in applying this mycoremediation tool. Mushrooms require time to adapt to the environment and cleanup wastes. Mushroom cultivated on industrial wastes may possess toxicity/genotoxicity. Genotoxicity of mushrooms is influenced by genotoxicants that are present in waste used for their cultivation. Therefore, it is necessary to assess toxicity/genotoxicity of mushrooms if used for bioremediation purpose.

Toxicity level in the fruiting bodies is based on two facts, i.e. biodegradation and biosorption. Mushroom possesses the suitable enzymatic machinery for biodegradation which lead to the degradation of pollutants from the substrate and convert it into less toxic products. This renders the fruiting bodies safe for consumption. Recently, many papers have published which reported that mushroom not only able to degrade pollutants but also able to reduce the toxicity or mutagenicity (Kulshreshtha et al. 2013b; Choi et al. 2013; Malachová et al. 2006). Numerous studies stated that mutagenicity reduction by mushrooms is primarily species dependent. Kulshreshtha et al. (2011) and Kulshreshtha et al. (2013b) reported Pleurotus florida was not found to have genotoxicity, however, Pleurotus citrinopileatus have had genotoxicity in their fruiting bodies when both were cultivated on industrial wastes and the mixture of wheat straw and industrial wastes under the same cultivation conditions.

Toxicity reduction is also dependent on the substrate. Same fungi may have different capability in degrading the different pollutants (Choi et al. 2013) due to the enzymes of mushrooms that are not only involved in degradation but also reducing the effects of toxic and genotoxic pollutants. Several researchers have proved the antimutagenic and antigenotoxic power of mushroom (Mendez-Espinoza et al. 2013; Taira et al. 2005; Mlinaric et al. 2004; Filipic et al. 2002; Menoli et al. 2001) which may be used to reduce the genotoxicity of the pollutants. Therefore, it is proved that besides having degradation power mushrooms can reduce the genotoxicants and toxic pollutants due to having antimutagenic and antigenotoxic power. These types of species of mushroom can be used for edible purposes and as feed for animals. This concept provides a natural guide to future research which should be focused on the need of research to degrade the pollutants in such a way that their disposal will not create another problem and fruiting bodies can be consumed safely. In contrast to this, absorption of pollutants by mushroom makes them unsuitable for consumption. Many researchers have reported the very high amount of metal content and mutagenicity in the fruiting bodies of mushrooms growing on polluted substrate, naturally or artificially, which is due to the absorption process (Tables 3 and 5). Wild Further information is needed about the level of toxicity in these mushrooms, ignorance of which will cause the associated health related problems.

Biosorption can become a good tool to remediate toxic metals threatening the environment (Lamrood and Ralegankar 2013) but on the other hand, this process generates non-consumable biomass which gives rise to the new problem of disposing it. Usually researchers have been focused on the use of mushroom mycelium for biosorption and compare the abilities of biomass for sorption (Table 3). A very few publications reported the reason of varying power of biosorption to various types of mushroom (Kumhomkul and Panich-pat 2013; Das 2005). This fact may be a decisive factor for further use of mushroom species.

It is proved that mushrooms have different abilities of biosorption, bioremediation, biodegradation and toxicity reduction. In my opinion, researchers should try to first remediate the heavy metals by cultivating high metal absorbing species of mushroom. However, low absorbing

\section{Table 5 Mutagenicity of naturally occurring and cultivated mushroom species detected by Ames test}

\begin{tabular}{|c|c|c|c|}
\hline S. no. & Mushroom types & Mutagenicity test results & Reference \\
\hline 1 & $\begin{array}{l}\text { Nine wild and two cultivated species of Spanish } \\
\text { edible mushrooms }\end{array}$ & The mushrooms were mutagenic to TA100 and TA98 strains & Morales et al., (1990) \\
\hline 2 & Wild and commercially grown mushrooms & $\begin{array}{l}\text { Presence of microsomal enzymes (S-9) reduced the } \\
\text { mutagenic effects of all the mushrooms, with the exception } \\
\text { of Agaricus abruptibulbus and Cantharellus cibarius. }\end{array}$ & Gruter et al., (1991) \\
\hline 3 & Agaricus bisporus & $\begin{array}{l}\text { Direct-acting mutagenic response in various Salmonella } \\
\text { typhimurium strains, TA104. Agaritine is not responsible } \\
\text { for the mutagenicity of mushroom extracts }\end{array}$ & Papaparaskeva et al., (1991) \\
\hline 4 & Agaricus bisporus & $\begin{array}{l}\text { Agaritine was weakly mutagenic, in the absence of an } \\
\text { activation system, in Salmonella typhimurium strain TA104. }\end{array}$ & Walton et al., (1997) \\
\hline 5 & $\begin{array}{l}\text { Pleurotus florida cultivated on handmade paper } \\
\text { and cardboard industrial waste }\end{array}$ & Not mutagenic with either TA 98 or TA 100 strain & Kulshreshtha et al., (2011) \\
\hline 6 & $\begin{array}{l}\text { Pleurotus citrinopileatus cultivated on handmade } \\
\text { paper and cardboard industrial waste }\end{array}$ & Mushroom extract is mutagenic with TA 98 strain & Kulshreshtha et al., (2013) \\
\hline
\end{tabular}


edible species can be used to cultivate on waste so that absorption of the pollutants can be minimized. Researchers should also try to develop the method of using biomass repeatedly for the biosorption of pollutants which will also reduce the waste generation. The toxicity or genotoxicity of these mushroom species should be assessed and thereafter, non-toxic mushroom species can be used for consumption. However, in the case of remediation of pollutants preference should be given to those species which can degrade the pollutants. The safe species will be selected to remediate a particular type of waste and further use for consumption.

\section{Conclusion}

Mushroom is a tremendous boon to the idea of using this for mycoremediation process as a real-world solution. The cultivation of edible mushroom on agricultural and industrial wastes may thus be a value added process capable of converting these discharges, which are otherwise considered to be wastes, into foods and feeds. Besides producing nutritious mushroom, it reduces genotoxicity and toxicity of mushroom species. Mycoremediation through mushroom cultivation will alleviate two of the world's major problems i.e. waste accumulation and production of proteinaceous food simultaneously. Thus, there is a need for further research towards the exploitation of potential of mushroom as bioremediation tool and its safety aspects for consumption as product.

\section{Competing interests}

The authors declare that they have no competing interests.

\section{Acknowledgement}

We are thankful to Rajasthan Department of Science and Technology (DST), Jaipur for providing financial support for conducting work (Sanction No. 2005/3951-67). We are also thankful to University Grants commission (UGC) for their support and grant (F. No. 40-113/2011, SR). We are also thankful to DST (Delhi), and Center for International Co-operation in Science (CICS), Chennai for providing travel grant to present my research in an International conference "Bioproduct-2012".

\section{Author details}

${ }^{1}$ Amity Institute of Biotechnology, Amity University Rajasthan, 14- Gopal Bari, Ajmer Road, A-200, Vaishali Nagar, Jaipur 302021, Rajasthan, India.

${ }^{2}$ Department of Zoology, University of Rajasthan, JLN Marg, Jaipur 302005, India. ${ }^{3}$ Department of Life Sciences, The IIS University, Gurukul Marg, Mansarovar, Jaipur 302020, India.

Received: 15 January 2014 Accepted: 17 January 2014

Published online: 01 April 2014

\section{References}

Ajith TA, Janardhanan KK (2007) Indian Medicinal Mushrooms as a Source of Antioxidant and Antitumor Agents. J Clin Biochem Nutr 40:157-162, doi:10.3164/jcbn.40.157

Akinyele BJ, Olaniyi OO, Arotupin DJ (2011) Bioconversion of selected agricultural wastes and associated enzymes by Volvariella volvacea: An edible mushroom. Res J Microbiol 6:63-70, doi:10.3923/jm.2011.63.70

Akinyele JB, Fakoya S, Adetuyi CF (2012) Anti-growth factors associated with Pleurotus ostreatus in a submerged liquid fermentation. Malaysian J Microbiol 8:135-140
Belewu MA, Belewu KY (2005) Cultivation of mushroom (Volvariella volvacea) on banana leaves. African J Biotechnol 4:1401-1403

Brienzo M, Silva EM, Milagres AM (2007) Degradation of eucalyptus waste components by Lentinula edodes strains detected by chemical and near-infrared spectroscopy methods. Appl Biochem Biotechnol 141:37-50

Choi YS, Long Y, Kim MJ, Kim JJ, Kim GH (2013) Decolorization and degradation of synthetic dyes by Irpex lacteus KUC8958. J Environ Sci Health A Tox Hazard Subst Environ Eng 48:501-508, doi:10.1080/10934529.2013.730419

Da Luz JMR, Paes SA, Nunes MD, da Silva MCS, Kasuya MCM (2013) Degradation of Oxo-Biodegradable Plastic by Pleurotus ostreatus. PLoS ONE 8(8):69386, doi:10.1371/journal.pone.0069386

Das N (2005) Heavy metals biosorption by mushrooms. NPR 4:454-459

Dulay RMR, Parungao AG, Kalaw SP, Reyes RG (2012) Aseptic cultivation of Coprinus comatus (O. F. Mull.) Gray on various pulp and paper wastes. Mycosphere 3:392-397, doi:10.5943/mycosphere/3/3/10. 392

Eskander SB, Abd El-Aziz SM, El-Sayaad H, Saleh HM (2012) Cementation of bioproducts generated from biodegradation of radioactive cellulosic-based waste simulates by mushroom. ISRN Chemical Engineering, doi:10.5402/ 2012/329676

Filipic M, Umek A, Mlinaric A (2002) Screening of Basidiomycete mushroom extracts for antigenotoxic and bio-antimutagenic activity. Harmazie 57:416-420

Gaitán-Hernández R, Esqueda M, Gutiérrez A, Sánchez A, Beltrán-García M, Mata G (2006) Bioconversion of agrowastes by Lentinula edodes: The high potential of viticulture residues. Appl Microbiol Biot 71:432-439, doi:10.1590/S1517-83822011000100004

Gameiro PH, Nascimento JS, Rocha BH, Piana CF, Santos RA, Takahashi CS (2013) Antimutagenic effect of aqueous extract from Agaricus brasiliensis on culture of human lymphocytes. J Med Food 16:180-183, doi:10.1089/jmf.2012.0068

Gao Y, Dai X, Chen G, Ye J, Zhou S (2003) A randomized, placebo-controlled, multicenter study of Ganoderma lucidum (W. Curt.Fr.) Lloyd (Aphylloromycetidae) polysaccharides (Ganopoly R) in patients with advanced lung cancer. Int J Med Mushrooms 5:369-381

Gavrilescu M (2004) Removal of heavy metals from the environment by biosorption. Eng Life Sci 4:219-232, doi:10.1002/elsc.200420026

Gruter A, Friederich U, Wurgler FE (1991) The mutagenicity of edible mushrooms in a histidine-independent bacterial test system. Food Chem Toxicol 29:159-65

Hammel KE, Green B, Gai WZ (1991) Ring fission of anthracene by a eukaryote. Proc Natl Acad Sci USA 88:10605-10608, doi:10.1073/pnas.88.23.10605

Heinfling MJ, Martínez AT, Martínez M, Bergbauer Szewzyk U (1998) Transformation of industrial dyes by manganese peroxidases from Bjerkandera adusta and Pleurotus eryngii in a manganese-independent reaction. Appl Environ Microbiol 64:2788-2793

Jang KY, Cho SM, Seok SJ, Kong WS, Kim GH, Sung JM (2009) Screening of biodegradable function of indigenous ligno-degrading mushroom using dyes. Mycobiology 37:53-61, doi:10.4489/MYCO.2009.37.1.053

Jibran AK, Milsee Mol JP (2011) Pleurotus sajor-caju Protein: A potential biosorptive agent. Adv Bio Tech 11:25-27

Johannes C, Majcherczyk A, Hüttermann A (1996) Degradation of anthracene by laccase of Trametes versicolor in the presence of different mediator compounds. Appl Microbiol Biot 46:313-317, doi:10.1007/s002530050823

Jonathan SG, Fasidi IO, Ajayi AO, Adegeye O (2008) Biodegradation of Nigerian wood wastes by Pleurotus tuber-regium (Fries) Singer. Bioresource Technol 99:807-811, doi:10.1016/j.biortech.2007.01.005

Kang MY, Rico CW, Lee SC (2012) In vitro antioxidative and antimutagenic activities of oak mushroom (Lentinus edodes) and king Oyster mushroom (Pleurotus eryngii) byproducts. Food Sci Biotechnol 21:167-173, doi:10.1007/s10068-012-0021-5

Kodama N, Komuta K, Nanba H (2002) Can maitake MD-fraction aid cancer patients? Altern Med Rev 7:236-239

Kuforiji OO, Fasidi IO (2008) Enzyme activities of Pleurotus tuber-regium (Fries) Singer, cultivated on selected agricultural wastes. Bioresource Technol 99:4275-4278, doi:10.1016/j.biortech.2007.08.053

Kuforiji OO, Fasidi IO (2009) Biodegradation of agro-industrial wastes by an edible mushroom Pleurotus tuber-regium (Fr.). J Environ Biol 30:355-358

Kulshreshtha S, Mathur N, Bhatnagar P (2011) Pros and cons of P.florida cultivation for managing waste of handmade paper and cardboard industries. IIOAB Journal, spl 2:45-48

Kulshreshtha S, Mathur N, Bhatnagar P (2013a) Mycoremediation of paper, pulp and cardboard industrial wastes and pollutants. In: Goltapeh EM, Danesh YR, 
Varma A (eds) Fungi as Bioremediators: Soil Biology. Springer Berlin, Heidelberg, pp 77-116

Kulshreshtha S, Mathur N, Bhatnagar P, Jain BL (2010) Bioremediation of industrial wastes through mushroom cultivation. J Environ Biol 31:441-444

Kulshreshtha S, Mathur N, Bhatnagar P, Kulshreshtha S (2013b) Cultivation of Pleurotus citrinopileatus on handmade paper and cardboard industrial wastes. Ind Crop Prod 41:340-346

Kumhomkul T, Panich-pat T (2013) Lead accumulation in the straw mushroom, Volvariella volvacea, from lead contaminated rice straw and stubble. Bull Environ Contam Toxicol 91:231-234, doi:10.1007/s00128-013-1025-4

Lamrood PY, Ralegankar SD (2013) Biosorption of Cu, Zn, Fe, Cd, Pb and Ni by non-treated biomass of some edible mushrooms. Asian J Exp Biol Sci 4:190-195

Lechner BE, Papinutti VL (2006) Production of lignocellulosic enzymes during growth and fruiting of the edible fungus Lentinus tigrinus on wheat straw. Process Biochem 41:594-598, doi:10.1016/j.procbio.2005.08.004

Lin JE, Wang HY, Hickey RF (1990) Degradation kinetics of pentachloro-phenol by Phanerochaete chrysosporium. Biotechnol Bioeng 35:1125-1134, doi:10.1002/bit.260351108

Luo D, Yf X, Tan ZL, Li XD (2013) Removal of $\mathrm{Cu}^{2+}$ ions from aqueous solution by the abandoned mushroom compost of Flammulina velutipes. J Environ Biol 34:359-365

Mabrouk EM, Ahwany MD (2008) Production of mannanase by Bacillus amylolequifaciens 10A1 cultured on potato peels. Afr J Biotechnol 7:1123-1128, doi:10.5897/AJB08.047

Maehara Y, Tsujitani S, Saeki H, Oki E, Yoshinaga K, Emi Y, Morita M, Kohnoe S, Kakeji Y, Yano T, Baba H (2012) Biological mechanism and clinical effect of protein-bound polysaccharide $\mathrm{K}$, review of development and future perspectives. Surg Today 42:8-28, doi:10.1007/s00595-011-0075-7

Malachová K, Pavlícková Z, Novotný C, Svobodová K, Lednická D, Musílková E (2006) Reduction in the mutagenicity of synthetic dyes by successive treatment with activated sludge and the ligninolytic fungus Irpex lacteus. Environ Mol Mutagen 47:533-540 doi:10.1002/em.20224

Mar'in A, Conti C, Gobbi G (1997) Sorption of lead and caesium by mushrooms grown in natural conditions. Res Environ Biotechnol 2:35-49

Martín MC, González BA, Blanco SMJ (2004) Biological treatments for contaminated soils: hydrocarbon contamination. Fungal applications in bioremediation treatment. Rev Iberoam Micol 21:103-120

Mendez-Espinoza C, Garcia-Nieto E, Esquivel AM, Gonzalez MM, Bautista EV, Ezquerro CC, Santacruz LJ (2013) Antigenotoxic potential of aqueous extracts from the chanterelle mushroom, Cantharellus cibarius (higher Basidiomycetes) on human mononuclear cell cultures. Int J Med Mushrooms 15:325-32, doi:10.1615/IntJMedMushr.v15.i3.90

Menoli RC, Mantovani MS, Ribeiro LR, Speit G, Jordão BQ (2001) Antimutagenic effects of the mushroom Agaricus blazei Murrill extracts on V79 cells. Mutat Res 496:5-13, doi:10.1016/S1383-5718(01)00227-3

Mlinaric A, Kac J, Fatur T, Filipic M (2004) Anti-genotoxic activity of the mushroom Lactarius vellereus extract in bacteria and in mammalian cells in vitro. Pharmazie 59:217-221

Morales P, Bermúdez E, Hernández PE, Sanz B (1990) The mutagenicity of some Spanish edible mushrooms in the ames test. Food Chem 38:279-288

Nagy B, Măicăneanu A, Indolean C, Mânzatu C, Silaghi-Dumitrescu MC (2013) Comparative study of $\mathrm{Cd}(\mathrm{II})$ biosorption on cultivated Agaricus bisporus and wild Lactarius piperatus based biocomposites. Linear and nonlinear equilibrium modelling and kinetics J Taiwan Inst Chem E. doi:10.1016/j.jtice.2013.08.013

Novotný C, Svobodová K, Erbanová P, Cajthaml T, Kasinath A, Lang E, Šašeka V (2004) Ligninolytic fungi in bioremediation: extracellular enzyme production and degradation rate. Soil Biol Biochem 36:1545-1551, doi:10.1016/j.soilbio.2004.07.019

Nyanhongo GS, Gübitz G, Sukyai P, Leitner C, Haltrich D, Ludwig R (2007) Oxidoreductases from Trametes spp. in biotechnology: A wealth of catalytic activity. Food Technol Biotechnol 45:250-268

Oei P (2003) Mushroom cultivation, appropriate technology for mushroom growers. Backhugs Publishers, Leiden, The Netherlands

Ollikka P, Alhonmäki K, Leppänen VM, Glumoff T, Raijola T, Suominen I (1993) Decolorization of azo, triphenylmethane, heterocyclic, and polymeric dyes by lignin peroxidase isoenzymes from Phanerochaete chrysosporium. Appl Environ Microbiol 59:4010-4016
Olusola SA, Anslem EE (2010) Bioremediation of a crude oil polluted soil with Pleurotus Pulmonarius and Glomus Mosseae using Amaranthus Hybridus as a test plant. J Bioremed Biodegrad 1:111, doi:10.4172/2155-6199.1000113

Oyetayo VO, Adebayo AO, Ibileye A (2012) Assessment of the biosorption potential of heavy metals by Pleurotus tuber-regium. Int J Advanced Biol Res 2:293-297

Papaparaskeva C, loannides C, Walker R (1991) Agaritine does not mediate the mutagenicity of the edible mushroom Agaricus bisporus. Mutagenesis 6:213-217

Purnomo AS, Mori T, Putra SR, Kondo R (2013) Biotransformation of heptachlor and heptachlor epoxide by white-rot fungus Pleurotus ostreatus. Int Biodeterior Biodegrad 82:40-44, doi:10.1016/j.ibiod.2013.02.013

Rajput Y, Shit S, Shukla A, Shukla K (2011) Biodegradation of malachite green by wild mushroom of Chhatisgrah. J Exp Sci 2:69-72

Rani P, Kalyani N, Prathiba K (2008) Evaluation of lignocellulosic wastes for production of edible mushrooms. Appl Biochem Biotechnol 151:151-159, doi:10.1007/s12010-008-8162-y

Singhal V, Kumar A, Rai JP (2005) Bioremediation of pulp and paper mill effluent with Phanerochaete chrysosporium. J Environ Biol 26:525-529

Sutherland C, Venkobachar C (2013) Equilibrium modeling of Cu (II) biosorption onto untreated and treated forest macro-fungus Fomes fasciatus. International Journal of Plant, Animal and Environment Sciences 3:193-203

Taira K, Miyashita Y, Okamoto K, Arimoto S, Takahashi E, Negishi T (2005) Novel antimutagenic factors derived from the edible mushroom Agrocybe cylindracea. Mutat Res 586:115-123, doi:10.1016/j.mrgentox.2005.06.007

Tay CC, Liew HH, Yin CY, Abdul-Talib S, Surif S, Suhaimi AA, Yong SK (2011) Biosorption of Cadmium ions using Pleurotus ostreatus: Growth kinetics, isotherm study and biosorption mechanism. Korean J Chem Eng 28:825-830, doi:10.1007/s11814-010-0435-9

Tsujiyama S, Muraoka T, Takada N (2013) Biodegradation of 2,4-dichlorophenol by shiitake mushroom (Lentinula edodes) using vanillin as an activator. Biotechnol Lett 35:1079-1083, doi:10.1007/s10529-013-1179-5

VanAcken LM, Godefroid CM, Peres H, Naveau ASN (1999) Mineralization of 14C-U ring labeled 4-hydroxylamino-2,6-dinitrotoluene by manganesedependent peroxidase of the white-rot basidiomycete Phlebia radiate. J Biotech 68:159-169

Walton K, Coombs MM, Catterall FS, Walker R, loannides C (1997) Bioactivation of the mushroom hydrazine, agaritine, to intermediates that bind covalently to proteins and induce mutations in the Ames test. Carcinogenesis 18:1603-1608

Zhu MJ, Du F, Zhang GQ, Wang HX, Ng TB (2013) Purification a laccase exhibiting dye decolorizing ability from an edible mushroom Russula virescens. Int Biodeterior Biodegrad 82:33-39, doi:10.1016/j.ibiod.2013.02.010

doi:10.1186/s13568-014-0029-8

Cite this article as: Kulshreshtha et al.: Mushroom as a product and their role in mycoremediation. AMB Express 2014 4:29.

\section{Submit your manuscript to a SpringerOpen ${ }^{\odot}$ journal and benefit from:}

- Convenient online submission

- Rigorous peer review

- Immediate publication on acceptance

- Open access: articles freely available online

- High visibility within the field

- Retaining the copyright to your article

Submit your next manuscript at $>$ springeropen.com 